\title{
Macroeconomic Variables on Stock Market Interactions: The Indian Experience
}

\author{
Prof. Mohi-u-Din Sangmi ${ }^{1}$, Mohd.Mubasher Hassan ${ }^{2}$, \\ Head,Department of Business \& Financial Studies, University of Kashmir. \\ Research Scholar, University of Kashmir.
}

\begin{abstract}
To examine the effect of macroeconomic variables on the stock price movement in Indian Stock Market. Six variables of macro-economy (inflation, exchange rate, Industrial production, MoneySupply, Goldprice, interest rate) are used as independent variables. Sensex, Nifty and BSE 100are indicated as dependent variable. The monthly time series data are gathered from RBI handbook over the period of April 2008 to June 2012. Multiple regression analysis is applied in this paper to construct a quantitative model showing the relationship between macroeconomics and stock price. The result of this paper indicates that significant relationship is occurred between macroeconomics variable's and stock price in India.
\end{abstract}

Key Words:Bombay Stock Exchange, National Stock Exchange, Arbitrage pricing theory

\section{Introduction}

The capital market promotes economic growth and prosperityby providing an investment channel thatcontributes to attract domestic and foreign capital. The aggregate performance of capital market can be easily seen by its indices that represent the movement of stock prices being traded in capital market.

As we know that the economic stability in a country could be measured by macroeconomics variables. Inflation, interest rate, and exchange rate are some macroeconomics variable that reflecteconomic condition in India and the economic condition will affect the industry condition which ultimately will affect the company activity, that is why it is said macroeconomic variables are factors that could not be controlled by the companies which might be affecting the volatility of the stock price. In modern portfolio theory, the Arbitrage Pricing Theory (APT) developed by Ross (1976)assumes that the return on asset is a linear function of various macroeconomic factors or theoretical market indices, where sensitivity to changes in each factor is represented by a factor-specific beta coefficient. The APT states that the realized return on asset is composed of the expected return on that asset at the beginning of a time period and the unexpected realization of krisk factors during that time period plus firm specific risk.

The aim of this paper is to analyze the effects of macroeconomic variables on the Indian Stock market in the APT framework. To have a deeper insight of this financial-economic phenomenon the three broad based and much observed indices of Indian stock market viz: Sensex, Nifty and BSE-100 are being analyzed based on monthly data from April 2008 to June 2012 by six macroeconomic fundamental indicators. The macroeconomic variables used in this study are whole sale price index, foreign exchange rate, industrial production index, money supply, gold price, money market interest rate, and. In the analyses of time series descriptive statistics, Jarque-Bera test, Unit root test, Correlation matrix, multi linear regression method, Durbin-Watson test and Whites Heterocadasticity test were used.

\section{Literature Review}

Many authors have tried to show reliable associations between macroeconomic variables and stock returns. They identified several key macroeconomic variables which influenced stock market returns based on the Arbitrage Pricing Theory (APT). A brief overview of the studies is presented in this section.

Maysami and Koh (2000) testedthe relationships between the Singapore stock index and selected macroeconomic variables over a seven-yearperiod from 1988 to 1995 and they found that there existed a positive relationship between stock returns and changes in money supply but negative relationships between stock returns with changes in price levels, short- and long-term interest rates and exchange rates. To examine the interdependence between stock markets and fundamental macroeconomic factors in the five South EastAsian countries (Indonesia, Malaysia, Philippines, Singapore, and Thailand) was the main purpose of Wongbangpo and Sharma (2002). Monthly data from 1985 to 1996 is used in this study to represent GNP, the consumer price index, the money supply, the interest rate, and the exchange rate for the five countries. Their results showed that high inflation in Indonesia and Philippines influences the long-run negative relation between stock prices and the money supply, while the money growth in Malaysia, Singapore, and Thailand induces the positive effect for their stock markets. The exchange rate variable is positively related to stock prices inIndonesia, Malaysia, and Philippines, yet negatively related in Singapore and Thailand. 
Similar research also has been done in New Zealand. Gan, Lee, Yon, and Zhang (2006) conduct a research to analyze the effect of seven macroeconomics variables (inflation rate, long term interest rate, short term interest rate, the real trade weighted exchange rate index, real gross domestic product, money supply, and domestic retail oil prices) to the New Zealand Stock Index (NZSE40) return for the period of January 1990 until January 2003. They are using co integration test, with specifically employ Johansen Multivariate, Grangercausality Test, and innovation accounting in processing the data. In general, the result shows that the NZSE40 is consistently determined by the interest rate, money supply, and real GDP.

Ahmad, Rehman, Raoof (2010) observed the impact of interest rate and exchange rate to the Stock Return in Pakistan. The dependent variable used in their research is the stock return of KSE-100, where the independent variables used are interest rate and exchange rate (Rs/USD). The data is collected from the State Bank of Pakistan and Karachi Stock Exchange over period of 1998 - 2009 on yearly basis. As a result of multiple regression model analysis, it shows that the change in interest rate and exchange rate has a significant impact on stock returns. The change in interest rate giving negative impact, while change in exchange rate giving positive to the stock returns.

AhmetBüyükşalvarcı(2010) analyze the effect of seven variables of macroeconomics in the Turkish Stock Exchange Market using the Arbitrage Pricing Theory framework. The method used in processing the datais Multiple Regression with seven variables macroeconomic (variables consumer price index, money market interest rate, gold price, industrial production index, oil price, foreign exchange rate and money supply) as independent variables and Turkish stock market Index (Istanbul Stock Exchange Index-100) as dependent variable. The data used are monthly basis over the period of January 2003 to March 2010. Asa result, interest rate, industrial production index, oil price, foreign exchange rate have a negative effect while money supply has positive impact on ISE-100 Index returns. Moreover, inflation rate and gold price do not have any significant effect on ISE-100 Index returns.

Xiufang Wang (2011) try to find some evidence on the relationship between stock price and macroeconomic variables (Real GDP, CPI, short term interest rate) in China Stock Market. The research is aim to estimate the volatility of each variable using Exponential Generalized Autoregressive Conditional Heteroskedasticity (EGARCH) and determine the causal relationship between the stock price volatility and macroeconomic variables by using Lag-Augmented VAR (LA-VAR) models. The first finding of these research is there is no causal relationship between stock price and real GDP volatility. Bilateral causal relationship is found between inflation and stock price volatility. Xiufang Wang (2010) also found that there is a unidirectional causal relationship between stock market volatility and interest rate volatility, with the direction from stock prices to the interest rate.

\section{Objectives if the study}

The Present study is aimed to achieve the following objectives:-

i. To study the relationship between stock prices and macro-economic variables in India

ii. To give suggestions, on the basis of study results, for policy formulation at the country level.

\section{Research Methodology}

On the basis of literature review these studies hypothesize the model between three leading Indian stock market indices namely Sensex, Nifty and BSE 100 and set of six macroeconomic variables. Thisstudy has used the following model.

SMI $=\beta_{0}+\beta_{1}$ WPI $+\beta_{2}$ ExR $+\beta_{3} I I P+\beta_{4} \mathrm{M} 3+\beta_{5} \mathrm{GP}+\beta_{6} \mathrm{IR}+v \mathrm{i}$

Where, SMI $=$ Monthly percentage change in the stock market index

WPI= Monthly percentage change in the Wholesale price index

$\mathrm{ExR}=$ Monthly change in the exchange rate

$\mathrm{IIP}=$ Monthly percentage change in the index of production

M3= Monthly change in the money supply

$\mathrm{GP}=$ Monthly change in the gold price

$\mathrm{IR}=$ Monthly change in the interest rate

$v \mathrm{i}=$ Error term

On the basis of the literature review, the following hypotheses have been generated.

- There is a positive effect of inflation on stock market return in India.

- There is a negative effect of exchange rateon stock market return in India.

- There is a positive effect of index of industrial production on stock market return in India.

- There is a positive effect of money supply on stock market return in India.

- There is a negative effect of gold price on stock market return in India.

- There is a negative effect of the interest on stock market return in India. 
In the above equation $\beta_{0}$ is constant and $\beta$ is coefficient of variables while $\varepsilon_{t}$ is the residual error of the regression. The ordinary least squares (OLS) method is used to compute the estimates of the regression model stated above and all estimations have been performed in the econometrical software program SPSS, whereas the ordinary calculations in Excel.

\section{Sampling and Data Collection Procedure}

The sampling period for the paper begins from April, 2008 and ends in June, 2012. Macro variables and stock indices data are collected from the Annual report of Reserve Bank of India.

\section{Measures of Variables}

\section{Stock Market Return}

The stock indices employed are Sensex,Nifty,BSE-100. Firstly from the daily closing price index, the monthly average price index is calculated. Then, the stock market return is calculated by the following formula (Pearce \&Roley, 1985).

$\mathrm{MR}=\{(\mathrm{Mt}-\mathrm{Mt}-1) / \mathrm{Mt}-1\} * 100$

Where, $\mathrm{Mt}=$ Average Monthly Closing price index of $\mathrm{t}$ time

Mt-1= Average Monthly Closing price index of $\mathrm{t}-1$ time

Thus the dependent variable is the Monthly percentage change of closing values of the respective indices.

\section{Inflation Rate}

Inflation rate has been calculated from Wholesale Price Index as per the following formula (Pearce \&Roley, 1985).

$\mathrm{IF}=\{($ WPIt-WPIt-1)/WPIt- 1$\} * 100$

Where WPIt : Monthly WPI in time $t$

WPIt-1: Monthly WPI in time t-1

\section{Exchange Rate}

Monthly change in weighted average exchange rate (the buying rate of the US dollar) is used and calculated by the below-mentioned formula (Joseph \&Vezos, 2006).

$\mathrm{ER}=($ ERt-ERt -1$)$

Where ERt: Monthly weighted average exchange rate in time $t$

ERt-1: Monthly weighted average exchange rate in time t-1

\section{Index of Production}

Percentage change in Monthly index of production has been used and calculated by the following formula (Pearce \&Roley, 1985).

$\mathrm{IP}=\{(\mathrm{IPt}-\mathrm{IPt}-1) / \mathrm{IPt}-1\}^{*} 100$

Where IPt: Monthly index of production in time $t$

IPt-1: Monthly index of production in time $\mathrm{t}-1$

\section{Money Supply}

Changes in Monthly money supply have been used and calculated by the following formula (Flannery \&Propakandis, 2002; Pearce \&Roley, 1985).

$\mathrm{MS}=(\mathrm{M} 2 \mathrm{t}-\mathrm{M} 2 \mathrm{t}-1)$

Where M2t: Monthly money supply (M2) in time t

M2t-1: Monthly money supply (M2) in time t-1

\section{Gold Price}

Monthly change in weighted average of gold price is used and calculated by the below-mentioned formula (Mohiuddin,2008).

$\mathrm{GP}=(\mathrm{GPt}-\mathrm{GPt}-1)$

Where GPt: Monthly weighted average of gold price in time $t$

GPt-1: Monthly weighted average of gold price in time $t-1$

\section{Interest Rate}

Monthly change in interest rate is used. It is the weighted average rate of the month end. The following formula is as follows (Joseph \&Vezos, 2006).

IR $=($ IRt-IRt-1)

Where IRt: Monthly interest rate in time t 
IRt-1: Monthly interest rate in time t-1

\section{Results\& Discussion}

Various descriptive statistics are calculated of the variables under studyin order to describe the basic characteristics of these variables. Table1 presents the descriptive statistics of the data, containing sample means, medians, maximums, minimums, standard deviations, skewness, kurtosis as well as the Jarque-Bera statistics and probabilities (p-values).

Table 1:Descriptive Statics of Study Variables.

\begin{tabular}{|c|c|c|c|c|c|c|c|c|c|}
\hline & Sensex & Nifty & $\begin{array}{l}B S E \\
100 \\
\end{array}$ & WPI & $\operatorname{Ex} .(\$)$ & IIP & M3 & Gold & MIR \\
\hline Mean & 0.3232 & 0.32 & $\begin{array}{l}- \\
0.46767 \\
-\end{array}$ & 0.5741 & 0.320156 & 0.504 & 737.5958 & 360.2 & 0.0406 \\
\hline $\begin{array}{l}\text { Median } \\
\text { Standard }\end{array}$ & 0.052 & 0.26 & 0.04056 & 0.5387 & 0.1689 & 0.117 & 577.255 & 346.1 & 0.045 \\
\hline Deviation & 7.3677 & 7.15 & 10.0416 & 0.7573 & 1.2118353 & 5.85 & 529.01683 & 738.7 & 0.678 \\
\hline Kurtosis & $\begin{array}{l}3.0659 \\
-\end{array}$ & $\begin{array}{l}2.72 \\
-\end{array}$ & $\begin{array}{l}8.17815 \\
-\end{array}$ & 2.4924 & -0.268993 & 0.664 & -0.694775 & 3.958 & $\begin{array}{l}3.4176 \\
-\end{array}$ \\
\hline Skewness & 0.0115 & 0.18 & 1.73882 & -0.61 & 0.2771453 & 0.057 & 0.359929 & 1.168 & 1.1709 \\
\hline Jarque-Bera & 0.0101 & 0.43 & 81.0567 & 3.6376 & 22.903236 & 11.39 & 29.519916 & 13.27 & 11.789 \\
\hline p-value & 0.9949 & 0.81 & $2.5 \mathrm{E}-18$ & 0.1622 & $1.063 \mathrm{E}-05$ & 0.003 & $3.889 \mathrm{E}-07$ & 0.001 & 0.0028 \\
\hline Range & $\begin{array}{l}45.633 \\
-\end{array}$ & $\begin{array}{l}43.6 \\
-\end{array}$ & $\begin{array}{l}67.3286 \\
-\end{array}$ & 4.4698 & 5.2641 & 28.87 & 2243.09 & 4418 & 3.75 \\
\hline Minimum & 24.336 & 23.7 & 45.3255 & -1.891 & -2.1721 & -13.9 & -365.08 & -1167 & -2.33 \\
\hline Maximum & 21.297 & 19.9 & $\begin{array}{l}22.0031 \\
-\end{array}$ & 2.5786 & 3.092 & 14.94 & 1878.01 & 3251 & 1.42 \\
\hline Sum & 16.158 & 16.2 & 23.3836 & 28.706 & 16.0078 & 25.18 & 36879.79 & 18008 & 2.03 \\
\hline Count & 50 & 50 & 50 & 50 & 50 & 50 & 50 & 50 & 50 \\
\hline
\end{tabular}

As it can be seen from the Table 1, all the variables are asymmetrical. More precisely, Sensex, Nifty,BSE-100, Wholesale price index, and Interest rate have a negative skewness, which indicates thefat tails on the left-hand side of the distribution. Kurtosis value of all variables also shows data is not normally distributed because valuesofkurtosis are deviated from 3. The calculated Jarque-Bera statistics and corresponding p-values are used to test for the normality assumption. Based on the Jarque-Bera statistics and p-values the joint null hypothesis $\left(\mathrm{H}_{0}\right)$ is rejected for all variables,except for Sensex and Nifty where null hypothesis was accepted. So the descriptive statistics shows that the values are not normally distributed about its mean and variance or in other word we can says no randomness in data and therefore, is sensitive to periodic change and speculation. This indicated that individual investor can earn considerably higher normal rate of profit from the Indian Stock Market. So the results of above descriptive statistics raise the issue the inefficiency of Indian stock market.

Time series data are assumed to be non-stationary and thus it is necessary to perform a pretest to ensure there is a stationary co-integration relationship among variables before proceeding with the OLS estimations, it is necessary to investigate the time series properties of the variables by utilizing unit root test. The Augmented Dickey Fuller test have been performed in this study. The ADF test results are resented in Table 2.

Table 2:Unit root test Results of Augmented Dickey-Fuller Test (Constant and Trend)

\begin{tabular}{|c|c|c|c|c|}
\hline Variables & Level & p-value & $\begin{array}{l}\text { First } \\
\text { difference }\end{array}$ & p-value \\
\hline $\begin{array}{ll}\text { BSE } & \text { Sensex } \\
\text { Index } & \end{array}$ & -2.41701 & 0.3705 & -4.10265 & $0.006174 *$ \\
\hline BSE 100 Index & 0.28712 & 0.9986 & -3.48946 & $0.04044 *$ \\
\hline Nifty & -1.61261 & 0.7884 & -3.90972 & $0.01168 *$ \\
\hline WPI & -4.56803 & $0.001116^{*}$ & -3.37547 & $0.05467 *$ \\
\hline $\operatorname{ExR}(\$)$ & -1.01721 & 0.9402 & -4.10671 & $0.006089 *$ \\
\hline IIP & -3.6286 & $0.02741 *$ & -4.24013 & $0.003826^{*}$ \\
\hline M3 & $-\overline{0}-462238$ & 0.9853 & -4.84631 & $0.0003549 *$ \\
\hline Gold Price & -1.27 & 0.8947 & -3.98929 & $0.009029 *$ \\
\hline Interest rate & -2.10047 & 0.545 & -3.70887 & $0.02169^{*}$ \\
\hline
\end{tabular}

Asterisk (*) indicatesrejection of null hypothesis of non-stationarity at the $5 \%$ level. 
Results clearly indicate that the index series are not stationary at level except Inflation rate and Industrial production but the first differences of the series are stationary, so the data is further analyzed at first difference. Another test to be conducted on the sample data is Ordinary Lest Square whose One of the basic assumptions is that regressors are not mutually correlated. If more than one of them is correlated with other, multicollinearity is said to exist. Logic behind assumption of no multicollinearity is simple that if two or more independent variables are linearly dependent on each other, one of them should be included instead ofboth, otherwise it will increase standard error thereby making our results biased. In order to check multicollinearity among independent variables, a Pearson's correlation analysis has been performed. A suggested rule of thumb is that if the pairwise correlation between two regressors is very high, in excess of 0.8 , multicollinearity may pose serious problem (Ahmet.B,2010). The correlation analysis results are reported in Table 3. Since the highest correlation numbers are lower than 0.8 , the results clearly show that none of the independent variables are highly correlated and no multicollinearity amongst independent variables exist.

Table 3: Correlation Matrix

\begin{tabular}{llllllllll}
\hline & Sensex & Nifty & $\begin{array}{c}\text { BSE } \\
\text { 100 }\end{array}$ & WPI & Ex. $\mathbf{( \$ )}$ & IIP & M3 & Gold & MIR \\
\hline Sensex & 1.0 & & & & & & & & \\
Nifty & 1.0 & 1.0 & & & & & & & \\
BSE & & & & & & & & & \\
$\mathbf{1 0 0}$ & 0.8 & 0.8 & 1.0 & & & & & & \\
WPI & 0.2 & 0.2 & 0.2 & 1.0 & & & & & \\
Ex.(\$) & -0.6 & -0.6 & -0.6 & -0.2 & 1.0 & & & & \\
IIP & 0.0 & 0.0 & 0.0 & -0.1 & 0.1 & 1.0 & & & \\
M3 & 0.1 & 0.1 & 0.1 & 0.0 & 0.0 & 0.1 & 1.0 & & \\
Gold & -0.2 & -0.2 & -0.2 & -0.1 & 0.2 & 0.0 & -0.1 & 1.0 & \\
MIR & 0.0 & 0.0 & 0.0 & 0.4 & 0.1 & 0.3 & -0.1 & 0.1 & 1.0 \\
\hline
\end{tabular}

Estimation Results from Multiple Regression Models.

\section{- Analysis of Sensex}

Table 4: Regression Statistic

\begin{tabular}{|l|l|}
\hline Multiple R & 0.6 \\
\hline R Square & 0.4 \\
\hline Adjusted R Square & 0.3 \\
\hline Standard Error & 6.1 \\
\hline Observations & 50.0 \\
\hline
\end{tabular}

The $\mathrm{R}$ value of 0.6 indicate the moderate correlation between Sensex with six macroeconomic variables. R square value of 0.4 shows that $40 \%$ of Sensex fluctuations could be explained by macroeconomics variable, while the $60 \%$ is explained by other factors.

\section{Table 5:Anova}

\begin{tabular}{|l|l|l|l|l|l|}
\hline & df & SS & MS & F & $\begin{array}{l}\text { Significance } \\
\text { F }\end{array}$ \\
\hline Regression & 6 & 1051.3 & 175.2 & 4.7 & 0.0 \\
\hline Residual & 43 & 1608.5 & 37.4 & & \\
\hline Total & 49 & 2659.9 & & & \\
\hline
\end{tabular}

From the Anova or $\mathrm{F}$ test, the value of $\mathrm{F}$ is 4.7 with significance of 0.000 . Because of the probability (level of significant) of 0.000 is less than 0.05 , it proves that inflation, exchangerate,Industrial production, Money supply, Gold price and interest rate are simultaneously affecting the Sensex price.

Table 6: Coefficient of Regression

\begin{tabular}{|l|l|l|l|l|l|l|}
\hline & Coefficients & Standard Error & t Stat & P-value & Lower 95\% & $\begin{array}{l}\text { Upper } \\
95 \%\end{array}$ \\
\hline Intercept & 0.8 & 1.8 & 0.4 & 0.7 & -2.8 & 4.3 \\
\hline WPI & 0.5 & 1.4 & 0.4 & 0.7 & -2.3 & 3.2 \\
\hline Ex.(\$) & -3.6 & 0.8 & -4.7 & 0.0 & -5.1 & -2.0 \\
\hline IIP & 0.1 & 0.2 & 0.5 & 0.6 & -0.2 & 0.4 \\
\hline M3 & 0.0 & 0.0 & 0.6 & 0.5 & 0.0 & 0.0 \\
\hline Gold & 0.0 & 0.0 & -0.8 & 0.4 & 0.0 & 0.0 \\
\hline IR & 0.5 & 1.6 & 0.3 & 0.8 & -2.7 & 3.6 \\
\hline
\end{tabular}


As for the individual coefficients of macroeconomic variables are concerned, none of the variables was found significant except Exchange rate with the theoretically expected sign. While Gold price and interest rate showed spurious results.

Table 7: Durbin-WatsonTest

\begin{tabular}{|c|c|c|}
\hline Observation & Predicted Sensex & Residuals \\
\hline 1 & -5.8 & 9.8 \\
\hline 2 & 0.0 & -11.5 \\
\hline 3 & 1.1 & -9.6 \\
\hline 4 & 2.5 & 4.8 \\
\hline 5 & -7.5 & 2.2 \\
\hline 6 & -10.4 & -13.9 \\
\hline 7 & -1.7 & -8.7 \\
\hline 8 & 0.7 & -0.1 \\
\hline 9 & -0.3 & -1.5 \\
\hline 10 & -2.0 & 0.3 \\
\hline 11 & -4.4 & 2.3 \\
\hline 12 & 6.2 & 15.1 \\
\hline 13 & 7.2 & 12.4 \\
\hline 14 & 4.0 & 9.3 \\
\hline 15 & -0.3 & -0.6 \\
\hline 16 & 1.9 & 3.4 \\
\hline 17 & 0.5 & 5.5 \\
\hline 18 & 7.5 & -4.5 \\
\hline 19 & 1.2 & -2.0 \\
\hline 20 & 1.6 & 0.8 \\
\hline 21 & 5.6 & -4.6 \\
\hline 22 & 0.2 & -6.4 \\
\hline 23 & 6.7 & 0.2 \\
\hline 24 & 4.6 & -2.4 \\
\hline 25 & -4.5 & -0.2 \\
\hline 26 & -1.8 & 4.5 \\
\hline 27 & 2.5 & 0.7 \\
\hline 28 & 1.2 & 0.6 \\
\hline 29 & 3.1 & 3.4 \\
\hline 30 & 9.1 & -4.5 \\
\hline 31 & -2.0 & 1.4 \\
\hline 32 & 2.9 & -3.9 \\
\hline 33 & 1.1 & -4.4 \\
\hline 34 & 1.3 & -7.8 \\
\hline 35 & 5.2 & -2.9 \\
\hline 36 & 3.1 & 2.2 \\
\hline 37 & -1.3 & -4.5 \\
\hline 38 & 1.7 & -2.2 \\
\hline 39 & 3.3 & -1.2 \\
\hline 40 & -5.2 & -4.0 \\
\hline 41 & -8.5 & 7.3 \\
\hline 42 & -3.1 & 3.9 \\
\hline 43 & -5.7 & 4.7 \\
\hline 44 & -2.5 & -1.8 \\
\hline 45 & 5.9 & -3.4 \\
\hline 46 & 8.7 & 0.3 \\
\hline 47 & -0.7 & -1.6 \\
\hline 48 & -4.2 & 3.4 \\
\hline 49 & -8.4 & 3.3 \\
\hline 50 & -4.3 & 6.4 \\
\hline
\end{tabular}

$\begin{array}{lrrrrr}\text { Numerator } & \mathbf{2 0 7 9 . 0 8 1 1 4 9} & \text { D } & \mathbf{1 . 2 9 2 5 4 2} & & \\ \text { Denomenator } & \mathbf{1 6 0 8 . 5 2 1 3 9 9} & & & & \\ \text { At } 5 \% \text { level of significance. } & & \mathbf{d l}=\mathbf{1 . 2 9 1} & \mathbf{d u = 1 . 8 2 2} & \text { 4-dl=2.709 } & \text { 4-du=2.178 } \\ \text { The } d \text { lies between } \text { dl and du so the D-W test is Inconclusive about autocorrelation } & \end{array}$

At $5 \%$ level of significance.
The $d$ lies between $\mathrm{dl}$ and du so the $\mathrm{D}-\mathrm{W}$ test is Inconclusive about autocorrelation.

Table8: Whites General Heterocadasticity Test.

\begin{tabular}{|l|l|l|l|l|}
\hline Observation & Residuals & Residuals Square & Predicted Sensex & Predicted Sensex Sq. \\
\hline 1 & 9.8 & 96.18 & -5.8 & 33.51 \\
\hline 2 & -11.5 & 132.29 & 0.0 & 0.00 \\
\hline 3 & -9.6 & 93.11 & 1.1 & 1.23 \\
\hline 4 & 4.8 & 23.07 & 2.5 & 6.41 \\
\hline
\end{tabular}


Macroeconomic Variables on Stock Market Interactions: The Indian Experience

\begin{tabular}{|c|c|c|c|c|}
\hline 5 & 2.2 & 4.97 & -7.5 & 56.60 \\
\hline 6 & -13.9 & 194.42 & -10.4 & 108.01 \\
\hline 7 & -8.7 & 75.47 & -1.7 & 2.89 \\
\hline 8 & -0.1 & 0.01 & 0.7 & 0.50 \\
\hline 9 & -1.5 & 2.14 & -0.3 & 0.06 \\
\hline 10 & 0.3 & 0.09 & -2.0 & 4.17 \\
\hline 11 & 2.3 & 5.13 & -4.4 & 19.01 \\
\hline 12 & 15.1 & 228.07 & 6.2 & 38.38 \\
\hline 13 & 12.4 & 153.46 & 7.2 & 51.53 \\
\hline 14 & 9.3 & 87.12 & 4.0 & 15.80 \\
\hline 15 & -0.6 & 0.42 & -0.3 & 0.12 \\
\hline 16 & 3.4 & 11.84 & 1.9 & 3.56 \\
\hline 17 & 5.5 & 29.85 & 0.5 & 0.28 \\
\hline 18 & -4.5 & 20.27 & 7.5 & 56.01 \\
\hline 19 & -2.0 & 4.15 & 1.2 & 1.43 \\
\hline 20 & 0.8 & 0.68 & 1.6 & 2.59 \\
\hline 21 & -4.6 & 21.18 & 5.6 & 31.33 \\
\hline 22 & -6.4 & 41.10 & 0.2 & 0.03 \\
\hline 23 & 0.2 & 0.03 & 6.7 & 45.48 \\
\hline 24 & -2.4 & 5.75 & 4.6 & 20.89 \\
\hline 25 & -0.2 & 0.03 & -4.5 & 20.60 \\
\hline 26 & 4.5 & 20.13 & -1.8 & 3.18 \\
\hline 27 & 0.7 & 0.47 & 2.5 & 6.18 \\
\hline 28 & 0.6 & 0.38 & 1.2 & 1.50 \\
\hline 29 & 3.4 & 11.43 & 3.1 & 9.54 \\
\hline 30 & -4.5 & 20.27 & 9.1 & 83.48 \\
\hline 31 & 1.4 & 1.90 & -2.0 & 3.95 \\
\hline 32 & -3.9 & 15.21 & 2.9 & 8.49 \\
\hline 33 & -4.4 & 18.98 & 1.1 & 1.32 \\
\hline 34 & -7.8 & 60.93 & 1.3 & 1.73 \\
\hline 35 & -2.9 & 8.25 & 5.2 & 27.07 \\
\hline 36 & 2.2 & 5.04 & 3.1 & 9.83 \\
\hline 37 & -4.5 & 20.32 & -1.3 & 1.63 \\
\hline 38 & -2.2 & 5.02 & 1.7 & 2.94 \\
\hline 39 & -1.2 & 1.33 & 3.3 & 10.75 \\
\hline 40 & -4.0 & 16.33 & -5.2 & 27.52 \\
\hline 41 & 7.3 & 53.59 & -8.5 & 71.60 \\
\hline 42 & 3.9 & 15.21 & -3.1 & 9.82 \\
\hline 43 & 4.7 & 22.39 & -5.7 & 32.18 \\
\hline 44 & -1.8 & 3.15 & -2.5 & 6.02 \\
\hline 45 & -3.4 & 11.56 & 5.9 & 34.71 \\
\hline 46 & 0.3 & 0.12 & 8.7 & 75.56 \\
\hline 47 & -1.6 & 2.68 & -0.7 & 0.52 \\
\hline 48 & 3.4 & 11.68 & -4.2 & 17.48 \\
\hline 49 & 3.3 & 10.75 & -8.4 & 70.73 \\
\hline 50 & 6.4 & 40.59 & -4.3 & 18.42 \\
\hline
\end{tabular}

Table 9: Associated analysis of Whites Hetoerocadasticity test

\begin{tabular}{|c|c|c|c|c|c|}
\hline \multicolumn{2}{|c|}{ Regression Statistics } & \multirow{8}{*}{5.206566064} & & & \\
\hline Multiple R & 0.322693851 & & & & \\
\hline R Square & 0.104131321 & & & & \\
\hline Adjusted & & & & & \\
\hline Square & 0.06600925 & & & & \\
\hline Standard Error & 49.05562751 & & & & \\
\hline Observations & 50 & & & & \\
\hline \multicolumn{5}{|l|}{ ANOVA } & \\
\hline & df & SS & MS & $\mathrm{F}$ & $\begin{array}{l}\text { Significance } \\
\mathrm{F}\end{array}$ \\
\hline Regression & 2 & 13146.57292 & 6573.286462 & 2.731523166 & 0.07546443 \\
\hline Residual & 47 & 113103.3657 & 2406.45459 & & \\
\hline Total & 49 & 126249.9387 & & & \\
\hline
\end{tabular}

\begin{tabular}{lllllll}
\hline & & & & & \multicolumn{2}{c}{ Upper } \\
& Coefficients & Standard Error & t Stat & P-value & Lower 95\% & $95 \%$ \\
\hline Intercept & 19.06881168 & 9.008683788 & 2.116714508 & 0.039606726 & 0.94567752 & 37.19195 \\
Predicted & -0.242779338 & 1.516503675 & -0.160091493 & 0.873495071 & -3.29359122 & 2.808033
\end{tabular}


$\mathrm{nR}^{2} \sim$ Chi-Square distribution with degrees of freedom 2 ,

$\mathrm{WGH}=5.20$

Critical value at $5 \%$ levelof significance and 2 degrees of freedom $=5.99$

We conclude on the basis of test , that there is no Heterocadasticity in the above model.

\section{- Analysis of Nifty}

Table 10: Regression Statistic

\begin{tabular}{|l|l|}
\hline Multiple R & 0.6 \\
\hline R Square & 0.4 \\
\hline $\begin{array}{l}\text { Adjusted R } \\
\text { Square }\end{array}$ & 0.3 \\
\hline Standard Error & 5.9 \\
\hline Observations & 50.0 \\
\hline
\end{tabular}

of. 4 shows that $40 \%$ of volatilityinNiftycould be explained by macroeconomics variable, while the $60 \%$ is explained by other factors.

\section{Table 11:Anova}

\begin{tabular}{|l|l|l|l|l|l|}
\hline & $\mathrm{df}$ & SS & MS & F & Significance F \\
\hline Regression & 6.0 & 1026.5 & 171.1 & 5.0 & 0.0 \\
\hline Residual & 43.0 & 1475.9 & 34.3 & & \\
\hline Total & 49.0 & 2502.4 & & & \\
\hline
\end{tabular}

From the Anova or $\mathrm{F}$ test, the value of $\mathrm{F}$ is 5.0 with significance of 0.000 . Because of the probability (level of significant) of 0.000 is less than 0.05 , it proves inflation, exchange rate,Industrial production, Money supply, Gold price and interest rate are simultaneously affecting the Nifty.

\section{Table 12:Coefficient of Regression}

\begin{tabular}{|l|l|l|l|l|l|l|}
\hline & Coefficients & $\begin{array}{l}\text { Standard } \\
\text { Error }\end{array}$ & t Stat & P-value & Lower 95\% & $\begin{array}{l}\text { Upper } \\
95 \%\end{array}$ \\
\hline Intercept & 0.7 & 1.7 & 0.4 & 0.7 & -2.7 & 4.1 \\
\hline WPI & 0.3 & 1.3 & 0.2 & 0.8 & -2.3 & 2.9 \\
\hline Ex.(\$) & -3.6 & 0.7 & -4.9 & 0.0 & -5.1 & -2.1 \\
\hline IIP & 0.1 & 0.2 & 0.6 & 0.5 & -0.2 & 0.4 \\
\hline M3 & 0.0 & 0.0 & 0.7 & 0.5 & 0.0 & 0.0 \\
\hline Gold & 0.0 & 0.0 & -0.7 & 0.5 & 0.0 & 0.0 \\
\hline IR & 0.6 & 1.5 & 0.4 & 0.7 & -2.4 & 3.6 \\
\hline
\end{tabular}

As for the individual coefficients of macroeconomic variables are concerned, none of the variables was found significant except Exchange rate with the theoretically expected sign. While Gold price and interest rate showed spurious results.

Table13 : Durbin-Watson Test

\begin{tabular}{|l|l|l|}
\hline Observation & Predicted Nifty & Residuals \\
\hline 1.0 & -5.7 & 8.3 \\
\hline 2.0 & -0.3 & -10.9 \\
\hline 3.0 & 1.2 & -8.8 \\
\hline 4.0 & 2.4 & 4.7 \\
\hline 5.0 & -7.2 & 2.4 \\
\hline 6.0 & -10.5 & -13.2 \\
\hline 7.0 & -2.0 & -9.7 \\
\hline 8.0 & 1.0 & 1.1 \\
\hline 9.0 & -0.3 & -1.1 \\
\hline 10.0 & -1.6 & 0.4 \\
\hline 11.0 & -4.1 & 3.5 \\
\hline 12.0 & 5.7 & 14.2 \\
\hline 13.0 & 7.1 & 10.7 \\
\hline 14.0 & 3.8 & 8.3 \\
\hline 15.0 & -0.5 & -1.6 \\
\hline 16.0 & 1.7 & 3.5 \\
\hline 17.0 & 0.6 & 5.7 \\
\hline 18.0 & 7.4 & -4.7 \\
\hline 19.0 & 1.1 & -2.0 \\
\hline
\end{tabular}


Macroeconomic Variables on Stock Market Interactions: The Indian Experience

\begin{tabular}{|c|c|c|}
\hline 20.0 & 1.6 & 1.3 \\
\hline 21.0 & 5.4 & -4.3 \\
\hline 22.0 & 0.1 & -6.3 \\
\hline 23.0 & 7.0 & 0.0 \\
\hline 24.0 & 4.2 & -1.9 \\
\hline 25.0 & -4.3 & -0.2 \\
\hline 26.0 & -1.6 & 4.3 \\
\hline 27.0 & 2.5 & 0.9 \\
\hline 28.0 & 1.1 & 0.7 \\
\hline 29.0 & 3.2 & 3.3 \\
\hline 30.0 & 9.5 & -4.6 \\
\hline 31.0 & -2.0 & 1.4 \\
\hline 32.0 & 2.9 & -4.3 \\
\hline 33.0 & 0.8 & -4.0 \\
\hline 34.0 & 1.4 & -8.0 \\
\hline 35.0 & 5.5 & -2.9 \\
\hline 36.0 & 2.9 & 2.6 \\
\hline 37.0 & -1.2 & -4.8 \\
\hline 38.0 & 1.7 & -2.0 \\
\hline 39.0 & 3.3 & -1.1 \\
\hline 40.0 & -4.7 & -4.5 \\
\hline 41.0 & -8.4 & 7.2 \\
\hline 42.0 & -3.3 & 4.2 \\
\hline 43.0 & -5.3 & 4.2 \\
\hline 44.0 & -2.2 & -2.2 \\
\hline 45.0 & 5.5 & -2.6 \\
\hline 46.0 & 8.8 & 1.2 \\
\hline 47.0 & -0.8 & -1.3 \\
\hline 48.0 & -4.4 & 3.6 \\
\hline 49.0 & -8.5 & 3.0 \\
\hline 50.0 & -4.0 & 6.2 \\
\hline
\end{tabular}

$\begin{array}{ccccc}\text { Numerator } & 1981.9 & \text { d } & 1.3 \\ \text { Denmerator } & 1475.9 & & \end{array}$

Denmerator $\mathbf{1 4 7 5 . 9}$

4- 4 -

At 5\% level of significance. $\quad$ dl=1.291 $\quad$ du=1.822 $\quad$ dl=2.709 $\quad$ du=2.178

The $\mathrm{d}$ lies between $\mathrm{dl}$ and du so the $\mathrm{D}-\mathrm{W}$ test is Inconclusive about autocorrelation.

Table14:Whites General Heterocadasticity Test

\begin{tabular}{|c|c|c|c|c|}
\hline Observation & Residuals & Residuals Square & Predicted Nifty & $\begin{array}{ll}\text { Predicted } & \text { Nifty } \\
\text { Square } & \end{array}$ \\
\hline 1.0 & 8.3 & 69.3 & -5.7 & 32.9 \\
\hline 2.0 & -10.9 & 119.3 & -0.3 & 0.1 \\
\hline 3.0 & -8.8 & 76.7 & 1.2 & 1.3 \\
\hline 4.0 & 4.7 & 22.4 & 2.4 & 5.5 \\
\hline 5.0 & 2.4 & 5.8 & -7.2 & 51.5 \\
\hline 6.0 & -13.2 & 174.5 & -10.5 & 109.8 \\
\hline 7.0 & -9.7 & 94.1 & -2.0 & 4.0 \\
\hline 8.0 & 1.1 & 1.3 & 1.0 & 1.0 \\
\hline 9.0 & -1.1 & 1.2 & -0.3 & 0.1 \\
\hline 10.0 & 0.4 & 0.2 & -1.6 & 2.7 \\
\hline 11.0 & 3.5 & 12.4 & -4.1 & 17.0 \\
\hline 12.0 & 14.2 & 201.0 & 5.7 & 32.7 \\
\hline 13.0 & 10.7 & 114.1 & 7.1 & 50.7 \\
\hline 14.0 & 8.3 & 68.5 & 3.8 & 14.5 \\
\hline 15.0 & -1.6 & 2.6 & -0.5 & 0.2 \\
\hline 16.0 & 3.5 & 12.6 & 1.7 & 2.9 \\
\hline 17.0 & 5.7 & 32.6 & 0.6 & 0.4 \\
\hline 18.0 & -4.7 & 21.7 & 7.4 & 55.3 \\
\hline 19.0 & -2.0 & 3.8 & 1.1 & 1.3 \\
\hline 20.0 & 1.3 & 1.8 & 1.6 & 2.6 \\
\hline 21.0 & -4.3 & 18.5 & 5.4 & 29.2 \\
\hline 22.0 & -6.3 & 39.5 & 0.1 & 0.0 \\
\hline 23.0 & 0.0 & 0.0 & 7.0 & 48.3 \\
\hline 24.0 & -1.9 & 3.7 & 4.2 & 17.5 \\
\hline 25.0 & -0.2 & 0.1 & -4.3 & 18.9 \\
\hline 26.0 & 4.3 & 18.4 & -1.6 & 2.6 \\
\hline 27.0 & 0.9 & 0.7 & 2.5 & 6.0 \\
\hline 28.0 & 0.7 & 0.5 & 1.1 & 1.2 \\
\hline
\end{tabular}


Macroeconomic Variables on Stock Market Interactions: The Indian Experience

\begin{tabular}{|l|l|l|l|l|}
\hline 29.0 & 3.3 & 11.1 & 3.2 & 10.0 \\
\hline 30.0 & -4.6 & 21.3 & 9.5 & 90.5 \\
\hline 31.0 & 1.4 & 1.9 & -2.0 & 4.2 \\
\hline 32.0 & -4.3 & 18.5 & 2.9 & 8.5 \\
\hline 33.0 & -4.0 & 15.6 & 0.8 & 0.6 \\
\hline 34.0 & -8.0 & 63.9 & 1.4 & 1.9 \\
\hline 35.0 & -2.9 & 8.7 & 5.5 & 30.1 \\
\hline 36.0 & 2.6 & 6.6 & 2.9 & 8.2 \\
\hline 37.0 & -4.8 & 22.9 & -1.2 & 1.3 \\
\hline 38.0 & -2.0 & 4.1 & 1.7 & 2.8 \\
\hline 39.0 & -1.1 & 1.1 & 3.3 & 11.1 \\
\hline 40.0 & -4.5 & 20.6 & -4.7 & 22.5 \\
\hline 41.0 & 7.2 & 51.4 & -8.4 & 70.1 \\
\hline 42.0 & 4.2 & 17.8 & -3.3 & 11.1 \\
\hline 43.0 & 4.2 & 17.7 & -5.3 & 28.2 \\
\hline 44.0 & -2.2 & 5.0 & -2.2 & 4.9 \\
\hline 45.0 & -2.6 & 6.9 & 5.5 & 30.3 \\
\hline 46.0 & 1.2 & 1.4 & 8.8 & 76.7 \\
\hline 47.0 & -1.3 & 1.6 & -0.8 & 0.6 \\
\hline 48.0 & 3.6 & 12.7 & -4.4 & 19.3 \\
\hline 49.0 & 3.0 & 9.1 & -8.5 & 72.2 \\
\hline 50.0 & 6.2 & 38.6 & -4.0 & 16.3 \\
\hline & & & \\
\hline
\end{tabular}

Table 15: Associated analysis of Whites Hetoerocadasticity test

Regression Statistics

\begin{tabular}{ll}
\hline Multiple R & 0.302631216 \\
R Square & 0.091585653 \\
Adjusted R & \\
Square & 0.052929723 \\
Standard Error & 42.81922068 \\
Observations & 50 \\
\hline
\end{tabular}

\subsection{3}

ANOVA

\begin{tabular}{llllll}
\hline & df & SS & MS & F & Significance \\
\hline Regression & 2 & 8687.9805 & 4343.99025 & 2.369252373 & 0.1046342 \\
Residual & 47 & 86173.82602 & 1833.48566 & & \\
Total & 49 & 94861.80652 & & & \\
\hline
\end{tabular}

\begin{tabular}{|c|c|c|c|c|c|c|}
\hline & \multicolumn{3}{|c|}{ Standard } & \multirow[b]{2}{*}{$\mathrm{P}$-value } & \multirow[b]{2}{*}{ Lower $95 \%$} & \multirow{2}{*}{$\begin{array}{l}\text { Upper } \\
95 \%\end{array}$} \\
\hline & Coefficients & Error & $\mathrm{t}$ Stat & & & \\
\hline Intercept & 19.75334816 & 7.742538349 & 2.551275469 & 0.014047135 & 4.17737008 & 35.32933 \\
\hline Predicted & - & & - & & - & \\
\hline $\begin{array}{l}\text { Nifty } \\
\text { Predicted }\end{array}$ & 0.699663669 & 1.337798143 & 0.522996442 & 0.603433736 & 3.39096639 & 1.991639 \\
\hline Nifty Square & 0.484166276 & 0.231927107 & 2.087579507 & 0.042282624 & 0.01758912 & 0.950743 \\
\hline
\end{tabular}

$\mathrm{nR}^{2} \sim$ Chi-Square distribution with degrees of freedom 2 ,

$\mathrm{WGH}=4.57$

Critical value at 5\% levelof significance and 2 degrees of freedom $=5.99$

We conclude on the basis of test, that there is no Heterocadasticity in the above model.

- Analysis of BSE 100.

Table 16: Regression Statistic

\begin{tabular}{|l|l|}
\hline Regression Statistics \\
\hline Multiple R & 0.991596771 \\
\hline R Square & 0.983264156 \\
\hline $\begin{array}{l}\text { Adjusted R } \\
\text { Square }\end{array}$ & 0.980928922 \\
\hline Standard Error & 1.382035489 \\
\hline Observations & 50 \\
\hline
\end{tabular}


The $\mathrm{R}$ value of 0.99 indicates high correlation between BSE-100with macroeconomic variables, $\mathrm{R}$ square value of 0.98 implies that $98 \%$ of BSE-100 price movement could be explained by six macroeconomics variable, while the $2 \%$ by unexplained factors.

Table 17:Anova

\begin{tabular}{|l|l|l|l|l|l|}
\hline ANOVA & & & & & \\
\hline & df & SS & MS & F & $\begin{array}{l}\text { Significance } \\
\text { F }\end{array}$ \\
\hline Regression & 6 & 4825.35697 & 804.22616 & 421.055947 & 0.0000 \\
\hline Residual & 43 & 82.13094999 & 1.9100221 & & \\
\hline Total & 49 & 4907.48792 & & & \\
\hline
\end{tabular}

From the Anova or $\mathrm{F}$ test, the value of $\mathrm{F}$ is $421.05 \&$ is significant at $5 \%$ at because of the probability (level of significant) of 0.000 is less than 0.05 , it proves that all six macroeconomic variables are simultaneously affecting the BSE-100 movement.

Table 18: Coefficient of Regression

\begin{tabular}{|l|l|l|l|l|l|l|}
\hline & Coefficients & Standard Error & t Stat & P-value & $\begin{array}{l}\text { Lower } \\
95 \%\end{array}$ & $\begin{array}{l}\text { Upper } \\
95 \%\end{array}$ \\
\hline Intercept & -0.44341 & 0.23327 & -1.90086 & 0.06404 & -0.91383 & 0.02702 \\
\hline WPI & 2.00552 & 0.86533 & 2.31763 & 0.02530 & 0.26041 & 3.75062 \\
\hline ExR & -6.29548 & 0.37727 & -16.6869 & 0.00000 & -7.05632 & -5.5346 \\
\hline IIP & 0.16238 & 0.05751 & 2.82349 & 0.00717 & 0.04640 & 0.27835 \\
\hline M3 & 0.00723 & 0.00069 & 10.41752 & 0.00000 & 0.00583 & 0.00863 \\
\hline GP & -0.00073 & 0.00040 & -1.83089 & 0.07405 & -0.00152 & 0.00007 \\
\hline IR & 5.55692 & 0.56701 & 9.80037 & 0.00000 & 4.41343 & 6.70041 \\
\hline
\end{tabular}

As for the individual coefficients of macroeconomic variables are concerned, quite interestingly six ofthe variables have theoretically expected signs with WPI,ExR,IIP,M3 influencing significantly, while gold price having expected sign but affecting insignificantly, on the contrary Interest rate have theoretically unexpected sign but influence significantly.

Table 19:Durbin-Watson Test

\begin{tabular}{|c|c|c|}
\hline Observation & Predicted BSE 100 & Residuals \\
\hline 1 & -1.0620283 & 1.5741254 \\
\hline 2 & 0.0694221 & -0.8411776 \\
\hline 3 & 0.1128322 & -0.6715090 \\
\hline 4 & 68.6398747 & 0.1194486 \\
\hline 5 & -7.0184752 & -0.9099287 \\
\hline 6 & -1.6852103 & -0.0802571 \\
\hline 7 & -1.8753364 & 0.8716480 \\
\hline 8 & -2.0007640 & 2.2138287 \\
\hline 9 & -0.9516093 & 0.6851657 \\
\hline 10 & -0.4031400 & 0.0204199 \\
\hline 11 & -2.8013159 & -1.5816224 \\
\hline 12 & 0.7886717 & 1.5384385 \\
\hline 13 & 1.8252450 & 1.3703331 \\
\hline 14 & 0.8176871 & 1.8430564 \\
\hline 15 & 0.6012426 & -0.7916568 \\
\hline 16 & 4.5647642 & 1.1707806 \\
\hline 17 & 8.3280928 & 3.5866571 \\
\hline 18 & 0.8335980 & -0.5546868 \\
\hline 19 & 0.4878664 & -0.5682828 \\
\hline 20 & 1.1975959 & 0.4165699 \\
\hline 21 & 1.1520056 & -1.0027791 \\
\hline 22 & -0.1573863 & -0.3749167 \\
\hline 23 & 2.5732972 & -1.6666396 \\
\hline 24 & 0.7673438 & -0.5208531 \\
\hline 25 & -1.2172699 & 0.0610953 \\
\hline 26 & 3.2383215 & -0.7136371 \\
\hline 27 & 2.4529662 & -1.6665768 \\
\hline 28 & -0.4444621 & 0.9343369 \\
\hline 29 & 2.7250573 & -0.6885939 \\
\hline 30 & 1.5416596 & -1.2414586 \\
\hline 31 & -0.6643703 & 0.3844289 \\
\hline 32 & 0.9409985 & -1.2003132 \\
\hline 33 & -0.0565269 & -0.3834480 \\
\hline 34 & 0.0960759 & -0.5574829 \\
\hline 35 & 1.7690050 & -1.4945558 \\
\hline
\end{tabular}


Macroeconomic Variables on Stock Market Interactions: The Indian Experience

\begin{tabular}{|l|l|l|}
\hline 36 & 2.0214938 & -0.8656634 \\
\hline 37 & -0.3008683 & -0.3085306 \\
\hline 38 & 0.2929880 & -0.3276821 \\
\hline 39 & 1.1127054 & -0.8570338 \\
\hline 40 & -0.6676573 & -0.2587213 \\
\hline 41 & -2.2800671 & 2.0764668 \\
\hline 42 & -2.2404880 & 2.6081319 \\
\hline 43 & -4.2205646 & 3.0807617 \\
\hline 44 & 0.5886470 & -1.4211680 \\
\hline 45 & 0.3943319 & -0.0388432 \\
\hline 46 & 2.0185985 & -0.6005657 \\
\hline 47 & 1.0044107 & -1.4763514 \\
\hline 48 & 0.1795743 & -1.6377339 \\
\hline 49 & -0.8568249 & -0.3917840 \\
\hline 50 & -0.1719672 & 1.1387600 \\
\hline
\end{tabular}

\section{Numera 119.1829 \\ Denome 82.13094999 $\quad d=\quad \mathbf{1 . 4 5 1 1 3 2 6 1 2}$}

At 5\% level of significance. $\quad \mathbf{d l}=\mathbf{1 . 2 9 1} \quad \mathbf{d u}=\mathbf{1 . 8 2 2} \quad$ 4-dl=2.709

The $\mathrm{d}$ lies between $\mathrm{dl}$ and du so the test is inconclusive about the presence of autocorrelation.

Table 20:Whites Heterocadasticity Test

\begin{tabular}{|c|c|c|c|c|}
\hline Observation & Residuals & Residuals square & $\begin{array}{l}\text { Predicted BSE } \\
100\end{array}$ & $\begin{array}{lll}\text { Predicted } & \text { BSE } & 100 \\
\text { Square } & & \\
\end{array}$ \\
\hline 1 & 1.574125 & 2.477871 & -1.062028 & 1.127904 \\
\hline 2 & -0.841178 & 0.707580 & 0.069422 & 0.004819 \\
\hline 3 & -0.671509 & 0.450924 & 0.112832 & 0.012731 \\
\hline 4 & 0.119449 & 0.014268 & 68.639875 & 4711.432395 \\
\hline 5 & -0.909929 & 0.827970 & -7.018475 & 49.258994 \\
\hline 6 & -0.080257 & 0.006441 & -1.685210 & 2.839934 \\
\hline 7 & 0.871648 & 0.759770 & -1.875336 & 3.516887 \\
\hline 8 & 2.213829 & 4.901038 & -2.000764 & 4.003057 \\
\hline 9 & 0.685166 & 0.469452 & -0.951609 & 0.905560 \\
\hline 10 & 0.020420 & 0.000417 & -0.403140 & 0.162522 \\
\hline 11 & -1.581622 & 2.501529 & -2.801316 & 7.847371 \\
\hline 12 & 1.538438 & 2.366793 & 0.788672 & 0.622003 \\
\hline 13 & 1.370333 & 1.877813 & 1.825245 & 3.331519 \\
\hline 14 & 1.843056 & 3.396857 & 0.817687 & 0.668612 \\
\hline 15 & -0.791657 & 0.626721 & 0.601243 & 0.361493 \\
\hline 16 & 1.170781 & 1.370727 & 4.564764 & 20.837072 \\
\hline 17 & 3.586657 & 12.864109 & 8.328093 & 69.357130 \\
\hline 18 & -0.554687 & 0.307677 & 0.833598 & 0.694886 \\
\hline 19 & -0.568283 & 0.322945 & 0.487866 & 0.238014 \\
\hline 20 & 0.416570 & 0.173531 & 1.197596 & 1.434236 \\
\hline 21 & -1.002779 & 1.005566 & 1.152006 & 1.327117 \\
\hline 22 & -0.374917 & 0.140563 & -0.157386 & 0.024770 \\
\hline 23 & -1.666640 & 2.777687 & 2.573297 & 6.621859 \\
\hline 24 & -0.520853 & 0.271288 & 0.767344 & 0.588817 \\
\hline 25 & 0.061095 & 0.003733 & -1.217270 & 1.481746 \\
\hline 26 & -0.713637 & 0.509278 & 3.238322 & 10.486726 \\
\hline 27 & -1.666577 & 2.777478 & 2.452966 & 6.017043 \\
\hline 28 & 0.934337 & 0.872985 & -0.444462 & 0.197547 \\
\hline 29 & -0.688594 & 0.474162 & 2.725057 & 7.425937 \\
\hline 30 & -1.241459 & 1.541219 & 1.541660 & 2.376714 \\
\hline 31 & 0.384429 & 0.147786 & -0.664370 & 0.441388 \\
\hline 32 & -1.200313 & 1.440752 & 0.940998 & 0.885478 \\
\hline 33 & -0.383448 & 0.147032 & -0.056527 & 0.003195 \\
\hline 34 & -0.557483 & 0.310787 & 0.096076 & 0.009231 \\
\hline 35 & -1.494556 & 2.233697 & 1.769005 & 3.129379 \\
\hline 36 & -0.865663 & 0.749373 & 2.021494 & 4.086437 \\
\hline 37 & -0.308531 & 0.095191 & -0.300868 & 0.090522 \\
\hline 38 & -0.327682 & 0.107376 & 0.292988 & 0.085842 \\
\hline 39 & -0.857034 & 0.734507 & 1.112705 & 1.238113 \\
\hline 40 & -0.258721 & 0.066937 & -0.667657 & 0.445766 \\
\hline 41 & 2.076467 & 4.311714 & -2.280067 & 5.198706 \\
\hline 42 & 2.608132 & 6.802352 & -2.240488 & 5.019787 \\
\hline 43 & 3.080762 & 9.491093 & -4.220565 & 17.813166 \\
\hline
\end{tabular}


Macroeconomic Variables on Stock Market Interactions: The Indian Experience

\begin{tabular}{|l|l|l|l|l|}
\hline 44 & -1.421168 & 2.019719 & 0.588647 & 0.346505 \\
\hline 45 & -0.038843 & 0.001509 & 0.394332 & 0.155498 \\
\hline 46 & -0.600566 & 0.360679 & 2.018598 & 4.074740 \\
\hline 48 & -1.476351 & 2.179613 & 1.004411 & 1.008841 \\
\hline 49 & -1.637734 & 2.682172 & 0.179574 & 0.032247 \\
\hline 50 & -0.391784 & 0.153495 & -0.856825 & 0.734149 \\
\hline
\end{tabular}

Table 21:Associated analysis of Whites Hetoerocadasticity test

\begin{tabular}{ll}
\hline \multicolumn{2}{c}{ Regression Statistics } \\
\hline Multiple R & 0.132106778 \\
R Square & 0.017452201 \\
& - \\
Adjusted R Square & 0.024358344 \\
Standard Error & 2.477617461 \\
Observations & 50 \\
\hline
\end{tabular}

\subsection{4}

ANOVA

\begin{tabular}{|c|c|c|c|c|c|c|}
\hline & df & SS & MS & $\mathrm{F}$ & $\begin{array}{l}\text { Significance } \\
\text { F }\end{array}$ & \\
\hline Regression & 2 & 5.1246343 & 2.56231714 & 0.417411466 & 0.661168 & \\
\hline Residual & 47 & 288.51365 & 6.13858828 & & & \\
\hline \multirow[t]{3}{*}{ Total } & 49 & 293.63828 & & & & \\
\hline & & Standard & & & & Upper \\
\hline & Coefficients & Error & t Stat & P-value & Lower $95 \%$ & $95 \%$ \\
\hline Intercept & 1.651164694 & 0.3557734 & 4.64105703 & $2.79912 \mathrm{E}-05$ & 0.935441 & 2.366888 \\
\hline Predicted BSE 100 & 0.112182092 & 0.160115 & 0.7006346 & 0.486985288 & -0.20993 & 0.434292 \\
\hline Predicted BSE 100 & - & & - & & & \\
\hline Square & 0.001942114 & 0.0023869 & 0.81366965 & 0.419937418 & -0.00674 & 0.00286 \\
\hline
\end{tabular}

$\mathrm{nR}^{2} \sim$ Chi-Square distribution with degrees of freedom 2 ,

$\mathrm{WGH}=.8726$

Critical value at $5 \%$ levelof significance and 2 degrees of freedom $=5.99$

We conclude on the basis of test, that there is no Homocadasticity in the above model.

\section{Conclusion}

Macroeconomics is considered as important factor for investing in India. It is proved that macroeconomics bring significant impact to the stock price. From the Sensex and Nifty, it is indicated that increase in inflation lead to higher stock price which is higher rate of return. In contrast, increase inexchange rate cause lower price of stock which result in lower return. Referring to the statistical result that there is a probability of other factor influencing stock price volatility, further research using other independent variables is necessary. This paper is one of the evidence of how macroeconomic variables affecting the stock price in Indian stock market. The model above are expected to be practical and used as a consideration for investor, company, and government in the future.

\section{References}

[1]. AhmetBuyukșalvarc1,(2010),:“The Effects Of Macroeconomics Variables On Stock Returns:Evidence From Turkey”, European Journal Of Social Sciences - Volume 14, Number 3.404-415.

[2]. Ahmad, Muhammad Ishfaq. Rehman, Ramizur. andRaoof, Awais, (2010). Do Interest Rate, Exchange Rate effect Stock Returns? A Pakistani Perspective.International Research Journal of Finance and Economics, [e-journal] 50,Available through: http://www.eurojournals.com/irjfe_50_12.pdf

[3]. Burmeister, Edwin, and K. Wall, (1986), "The Arbitrage Pricing Theory and Macroeconomic Factor Measures", Financial Review, 21, 1-20.

[4]. Chen, N.-F., R. Roll and S. A. Ross, (1986), "Economic Forces and the Stock Market", Journal of Business 59, 383-403.

[5]. Joseph N. L, \&Vezos, P. (2006)"The sensitivity of US banks to stock returns to interest rates \& exchange rates changes", Managerial Finance: 32, 182-199.

[6]. Christopher Gan, Minsoo Lee, HuaH.A.Yong,Jun Zhang.(2006) "Macroeconomic Variables And Stock Market Interactions: New Zealand Evidence". Investment Management and Financial Innovations, Volume 3(4),89-101.

[7]. Dhira.D,Anggoro.B and Novika.Candra (2012),"The Efffect of Macroeconomic Variables on Stock Price Volatility:Evidence from JakartaCompositeIndex,Agriculture,and Basic Industry Sector",IPEDR,Vol.46,18.

[8]. Fama, E. F. (1965,)” The Behavior of Stock-Market Prices”. Journal of Business, 38, 34-105. 
[9]. Maysami, R.C. and T.S. Koh A.(2000) "Vector Error Correction Model of the Singapore Stock Market", International Review of Economics and Finance, Vol. 9, 79-96.

[10]. Md. Mohiuddin, Md. DidarulAlam And Abdullah IbneyyShahid,(2008),“ An Empirical Study Of The Relationship Between Macroeconomic Variables And Stock Price: AStudy On Dhaka Stock Exchange (DSE)”,Working Paper No. AIUB-Bus-Econ-200821.

[11]. MuhammedMonjurulQuadir(2012), “The Effect Of Macroeconomic Variables On Stock Returns On Dhaka Stock Exchange", International Journal Of Economics And Financial Issues Vol. 2, No. 4, ,480-487.

[12]. Pearce, D. K. and Roley, V. V.( 1985). Stock prices and economic news, Journal of Business, 58(1): 49-67.

[13]. Wongbangpo, P., Sharma, S.C., (2002),"Stock market and macroeconomic fundamental dynamic interactions: ASEAN-5 countries", Journal of Asian Economics 13:1, 27-51.

[14]. Xiufang Wang,(2010,)" The Relationship Between Stock Market Volatility And Macroeconomic Volatility: Evidence From China",International Research Journal Of Finance And Economics Issn 1450-2887 Issue 49,149-160. 